\title{
Toward an ethically committed linguistics
}

\section{Kanavillil Rajagopalan Universidade Estadual de Campinas}

\section{Abstract}

The pivotal claim of this paper is that ethical issues are invariably present in Linguistics even at those moments when one is discussing what are presumably 'purely theoretical' problems. The reason why many linguists have difficulty in recognising this is that they are encumbered by a host of dogmas in relation to how a scientific area of study is constituted. Among these dogmas is the idea that the raw materials of the science of language are the so-called 'hard facts' - entities that are, by definition, devoid of any ultimate interests. It is further believed that all that Linguistics attempts to do is to describe them, or, following Chomsky's recommendation, explain the whys and wherefores of things, but always in ways that are purely internal to the phenomena in question. 


\section{THE BACKDROP}

\subsection{Objectives}

I

s there any room for ethical considerations in Linguistics? Should a linguist be attentive to the ideological underpinnings of her own theoretical reflections and those of the others whose views she is largely in sympathy with? To what extent is it reasonable to hold a linguist responsible for the ideological and political implications of the overall stance vis-à-vis language she has chosen to work with? Are all linguistic theories equally invested ideologically?

In the pages that follow, I would like to (a) suggest some explanation as to why many linguists believe, as I think they do, that most, or perhaps all, of the questions posed above should be answered in the negative (or, more accurately, why many linguists would answer the first question in the negative and hence summarily dismiss the others, given that all of them presuppose an affirmative answer to the first); (b) make some remarks as to what larger premises or unstated assumptions about science in general and linguistics in particular make them claim what they do and (c) argue why it is that, contrary to received opinion, I want to hold that any theoretical stance one may adopt vis-à-vis language will inevitably entail a certain ideological positioning and hence will necessarily have ethical consequences. ${ }^{1}$

\section{2. Science and ethics}

Questions such as the ones posed at the beginning of this paper are among those the answers to which depend, among other things, on a host of key assumptions about the status of linguistics as a science. Those of us who are anxious to see linguistics ranked as a natural science - or, Naturwissenschaft, as they say in German (as opposed to, say, a social science or one of the so-called 'humanities' 
- in German, Geisteswissenschaft) - are likely to maintain that, in so far as its pretensions are purely descriptive, linguistics knows no ethics and is innocent of all ideology. That is to say, a linguist qua linguist is not ethically liable and is ideologically neutral. Henry Widdowson $(1994,1995)$ has recently argued along these lines. He calls into question the pretensions of a group of researchers based at Lancaster University, U.K., who have been insisting for some time that work done in linguistics that does not have an immediate and direct bearing on real life issues is probably not worth the time and money expended upon it. They criticise a lot of work currently being done under the rubric of linguistics for being 'uncritical' and make a case for their own approach to language which they call 'Critical Discourse Analysis' (Cf. Fairclough, 1989a, 1989b). Widdowson's argument against the work of the Lancaster group rests on his belief that no research can be both analytical and critical - as he puts it himself, the combination of the two qualifiers yields "a contradiction in terms". Science is an analytical enterprise and hence can never aspire to be, in addition, critical. A scientist can only say how things are, not how they ought to be. The latter task is presumably best left to the care of daydreamers (poets, for instance) or professional meddlers (politicians, moral philosophers and the like). (See Rajagopalan, 1995 for a detailed analysis and lengthy critique of Widdowson's position).

The position firmly held by Widdowson and, apparently, by so many others amongst us, is heir to a long philosophical tradition that dates back to at least Aristotle who saw ethics as properly belonging to the realm of practical reason. Centuries later, Kant followed suit when he entitled his work on moral philosophy the Critique of Practical Reason (the more famous companion piece, the one on 'pure' reason, having been reserved for such 'more properly' philosophical concerns as ontology and epistemology). As a matter of fact, a cursory look at the history of Western philosophy will suffice to convince anyone that the idea that moral philosophy cannot have any factual base is a common ground for both the rationalists and 
the empiricists who see themselves as unrelenting rivals on every other conceivable issue.

Widdowson's thesis is also endorsed by and synthesised in one of the earliest rallying cries of Modern Linguistics - viz., that it is a descriptive, rather than a prescriptive enterprise. As the early defenders of the then fledgling science of linguistics never tired of insisting and indeed, as new recruits to the discipline are even today routinely harangued into believing, the traditional grammarians were thoroughly unscientific in that they were exclusively worried about telling people how they ought to speak their own language. ${ }^{2}$ By contrast, modern linguistics, we are told, is interested in describing how people in fact use their language and explaining what principles underlie their observable behaviour. Says Cattell (1966:6-7): "Whereas the older grammarians tried to lay down what sort of language ought to be used, the modern ones are more concerned with trying to describe what language is used."

In the words of Cameron (1985:70), “... it is in general true that linguists shy away from the ideological implications of their analyses." Indeed, one of their favourite methods "for distancing themselves from the political questions is the maintenance of theoretical fictions." (id. ibid.). Writing in much the same vein, McConnel-Ginet (1988: 75) asks: "Why have linguists been relatively inactive in the rapidly growing area of research on language and gender?", and goes on to answer the question herself: "Formal linguistics has little to say directly about language - the practice of using a language (i.e. a language system) or languages in a community and the relation of individuals to such systems and their use." (ibid)

Linguistics is, thus, institutionally given to denying all ethical liability, no matter what individual linguists may be inclined to say occasionally about the ethical dimension of their theoretical reflections. Furthermore, it seems reasonably clear that any discussion of the ethical dimension of linguistics crucially involves assumptions about the status of linguistics as a science (and, granted 
it is one, further assumptions as to what sort of a science it is - for instance, whether it is a natural science or a social science). ${ }^{3}$

\section{3. Ethics and ideology}

Our discussion thus far has been somewhat vitiated by the fact that the key terms 'ethics' and 'ideology' have been, as it were, 'bandied about' as though their meanings were too obvious and unequivocal to call for any explication. As is well known, however, both of them are open to several and often conflicting meanings. In this brief section, we shall try to sort out some of these different senses so as to avoid unnecessary detours later on.

There is a certain common element that one detects in the way the terms 'ethics' and 'ideology' are normally discussed in the literature. It is generally believed, for instance, that both are subjectively oriented. Besides, a philosopher who argues that ethical statements cannot be derived from factual ones is affirming that on the strength of a deep-seated conviction that facts are available for scrutiny by every Tom, Dick, and Harry, whereas values are always somebody's values, so that nothing prevents, say, Tom from subscribing to values that neither Dick nor Harry may be willing to subscribe to. This line of thought has recently been fully endorsed by Paul Simpson in his book Language, Ideology and Point of View (Simpson, 1993). The very aim of the book, as announced in the blurb on the back cover, is said to be "to explore [...] ways in which point of view intersects with and is shaped by ideology". In the introduction to the book, the author observes the following: "The elusive question of the 'truth' of what a text says is not an issue here; rather, it is the 'angle of telling' adopted in a text, whether this be an advertisement, a novel or a newspaper report." (Simpson, 1993: 2). It follows therefore that, for Simpson, the essential subjectivity of the "angles of telling" and hence also of the value-judgements that generally go with them have nothing to do with the absolute truth of whatever is in focus. Incidentally, I believe that Simpson is simply 
wrong in his claim, because the very idea of 'a point of view' makes sense just in case you implicitly assume a hypothetical Archimedian point in opposition to which one may go on to define it. (See Rajagopalan 1998a, for further comments on this).

The same holds good in the case of ideology as well. Leaving aside the catch-all - and, precisely for this reason, thoroughly unhelpful - use of the term to refer to any and every set of beliefs a person may entertain at a given moment, almost all the other meanings normally attached to the word 'ideology' seem to contain the feature 'subjective'. This is particularly evident in the use of the term in Marx and Engels (1845-7)'s The German Ideology. What the two writers claim here is that ideology is by and large the result of beliefs and motivations of an unconscious sort whose internal inconsistencies and overall untenability can only be brought to light by having recourse to enlightened theory, where everything is objective and accessible to all and sundry.

But Marx and Engels also introduced the one crucial element that has most characterised the use of the term 'ideology' since then: the idea that all ideologies contain a certain amount of falsehood and distortion. Thus in Marx and Engels' view the opposition between ideology and theory was actually a two-fold one. Ideology and theory were opposed to each other not only by the former being subjective and the latter objective, but in virtue of the fact that the former was false while the latter was true. Consequently, ideology became something which it was the duty of every right-thinking person to combat and overcome with the help of science (or theory, if you like) (On this issue, see Rajagopalan 1998c: 342ff).

Moving on now from ideology back to ethics, one immediately notices that what the philosophers often claim about ethical statements is not that they are false, but that they are not the sort of statements about which one can really say that they are either true or false. The logical positivists concluded from this that such statements were outright nonsense, alongside all claims of metaphysics, aesthetics, and theology. Ordinary language 
philosophers, amongst them notably R.M. Hare argued, on the other hand, that ethical statements were a case apart. With the glaring exception of J.L. Austin, who distinguished himself with his to-datelargely-unheeded claim that it had been his chief concern, all along, to "play Old Harry with" such venerable binary oppositions as 'truth vs. falsity' and 'fact vs. value' (Cf. Rajagopalan, 1994 and Rajagopalan, forthcoming, for more comments on this), what the philosophers in general have been concerned about is to carve out a separate niche for moral philosophy.

Ethical naturalism, the thesis that affirms that ethical conclusions can be straightforwardly inferred from factual premises has not found many supporters ever since G.E. Moore rejected it as a fallacy. Among contemporary philosophers, John Searle (Cf. Searle, 1969) has been waging a bold but lone battle against Moore's injunction (Philippa Foot, another philosopher who also once expressed some reservations on the issue, has revised her position since then), insisting that, at least in the case of a speech act such as promising, an 'ought' statement can be shown to follow from a set of 'is' statements (Searle's position too is beset with all manner of problems, but this is not the place to go into them - Cf. Rajagopalan, 1996, for a detailed analysis).

When all is said and done, the picture that seems to emerge is that ethics and ideology have been handled in our philosophical tradition along roughly the same lines, although individual philosophers may have every once in a while assumed different attitudes vis-à-vis each of these topics. Most philosophers who see themselves as belonging to the Establishment would rather have ideology contained, quarantined, and forced to give way to theory; as for ethical questions, the same philosophers are likely to say that, although from the point of view of 'meta-ethics', ethical statements do constitute a different class, issues of 'normative ethics' are by all means worthy of philosophical attention and are best settled on the firm basis of a theory of knowledge. In other words, paradoxical though it may appear at first sight, questions of morality, or of right 
and wrong, are best approached, so the argument goes, on the basis of results achieved in the great tradition of non-moral or amoral philosophy.

\section{4. Philosophy and linguistics}

We have already seen how linguistics is part of the great tradition in assuming theory's status as supra-ethical. But just as some philosophers feel that their essentially non-moral philosophy can help ground an entire system of moral philosophy, so too many linguists seem to believe that an ideologically neutral and ethically non-commital science of language can help guide practices that involve language in one way or another. Thus witness the following words by a leading socio-linguist, Peter Trudgill: "Linguists have an obligation to argue and work for linguistic equality, and linguistic rationality, ...”.(Trudgill, Cf. Afendras et al, 1995: 294)

Clearly, the obligation Trudgill is invoking is a moral obligation and his unstated justification will most probably be something like this: in so far she is a person endowed with the scientific knowledge about what languages are, what it is to be a speaker of a language, how human language is a sign of man's rational capacities, etc. etc. - in a nutshell, all those fundamental questions the answers to which are available today thanks to linguistics, her speciality, it is incumbent upon the linguist to argue and work for all those cherished goals etc. As a matter of fact, Trudgill's words had already been anticipated by Labov who, in a paper written some thirteen years earlier, had argued that linguists had a certain social responsibility towards the community at large, by which he meant, that linguists were expected to "pay their debt to the community by countering error and bias with the objective factual truth to which their expert status gives them privileged access" (Labov, 1982: 165). Barely a year before, the same Labov (1981) had cautioned the community about "the ideological use of the Neo-Grammarian principle", noting that "Scholars continue to search for universal principles by manipulating isolated examples - subtracting from the available data, rather than adding to them." 
In other words, although linguistics by itself does not tell you what ought to be the case, a knowledge of the fundamental principles of language will make you eminently qualified to dictate what ought to be the case and, furthermore, in so far as you now have that extra ability, it will behove you - nay, it will be your sacred duty and moral responsibility - to work for what you think ought to be the case. Practice only stands to gain by basing itself on knowledge; but not the other way round.

A clear statement of this view is to be found in Estrutura da Lingua Portuguesa by the celebrated Brazilian linguist Joaquim Mattoso Câmara (1904-1970): "Antes de tudo, a gramática normativa depende da lingüistica sincrônica ou gramática descritiva, em suma, para não ser caprichosa e contraproducente" (Câmara, Jr, 1970: v) (in English: Before anything else, a normative grammar is dependent on synchronic linguistics or descriptive linguistics so as not to be, to get straight to the point, capricious and counter-productive). The dangers of not paying attention to what the linguists had to say on such practical matters as language teaching had been clearly highlighted by Bloomfield as early as 1925. In his own words, "Our schools are conducted by persons who, from professors of education down to teachers in the classroom, know nothing of the results of linguistic research, not even the relation of writing to speech or of standard language to dialect. In short, they do not know what language is, and yet must teach it and in consequence waste years of every child's life and reach a poor result." (Bloomfield, 1925: 112)

Wilkins (1972:229) even admits the possibility that a practical concern such as language teaching may have very little to do with the high-falutin' theories churned out by theoretically-minded linguists. But no sooner has he made that audacious move, than he decides to beat the retreat and pay homage to the power of pure theory. Here is how he goes about it: "It is possible that linguistics is not even one of the most important elements in the preparation of a language teacher. The value of linguistics is that by increasing his awareness of language, it makes him more competent and therefore a better language teacher." 


\section{SPOTLIGHT ON THE SCENE}

\section{1. Ethics in linguistics}

Against the backdrop of the several issues discussed in the foregoing paragraphs, I wish to argue, from now on, that the question of ethics is inextricably intertwined with linguistics at even its most theoretical stage (and hence, contrary to the received opinion on this) and that perceiving the essentially ideological character of even the most abstruse of our theoretical principles and postulates entails a simultaneous re-thinking of some of the traditional ways of looking at our discipline. I shall, in effect, argue that linguistics is an ideological enterprise through and through; yet (paradoxical though it might indeed appear at first blush) by no means any the less theoretical for that reason. To the extent my reasoning is correct, it will have the consequence that all linguists, no matter how theoretical and ethically neutral they may regard their own research interests to be, are all saying things that have practical consequences and hence have an inseparable ethical dimension. In other words, the distinction between 'pure' and 'applied' sciences, whatever its usefulness in other fields, has little or no utility in the case of linguistics and only helps to obfuscate matters. Thus, when someone like Henry Widdowson, speaking on behalf of language teachers and others whose interest in language is presumably of a 'down-to-earth' and practical sort, insists that "... linguistics stands in need of interpretation" (Widdowson, 1979: 215) or again, "linguistics... requires the mediation of an interpreter for its potential usefulness to language teaching to be realised" (Widdowson, 1979: 217), he is - in all likelihood, albeit inadvertently - giving in to the conventional wisdom that pure science is not immediately or directly concerned with practical, and hence ethical issues.

In order to appreciate the ethical dimension of our theories about language, it is necessary as a first step to realise that linguistic theories are, like theories in every other field, concerted attempts at making sense of a certain 'chunk' of reality that baffles us - viz., 
language. Theories are, in other words, rationalisations that help us understand and cope with our reality. From this perspective, then, there is absolutely no difference between mythology and science, since both are systematic attempts at imparting meaning to an otherwise chaotic and mind-boggling phenomenon and both have, in their own proper settings, served their purposes admirably well at different moments in the history of mankind. In the case of linguistics, the difference between mythology (also called superstition or pre-scientific gibberish) and science translates as the difference between 'folk linguistics' and 'linguistics proper'. Theoretical linguists often speak derisively of folk linguistics as though there is always a cut-and-dry line of demarcation between the two. Nothing could be further from the truth. What gets the official stamp of approval is invariably a matter of what happens to be accepted as genuine science at a given moment in history which may or may not coincide with what was accepted by the preceding or the succeeding generation. This much is fairly uncontroversial. What is not often appreciated is that just as one man's meat may be another man's poison, so too nothing prevents one man's science from being another man's mythology (Cf. Rajagopalan, 1991: 124).

\subsection{Folk wisdom vs. the linguist's 'expert status'}

The distinction between 'folk theories' (many of us would probably balk at the very idea of calling them theories) and 'scientific theories' is of fundamental importance in the history of linguistics as a modern science. Some of Bloomfield's early papers attest to this. In his classic paper 'Secondary and tertiary responses to language' (Bloomfield, 1944), one comes across an early defence of the view that a field linguist should be careful not to confuse between what the native speaker of the language under investigation speaks in her language, and what she may occasionally feel tempted to say about the very same language.

Bloomfield's point is that of the two kinds of utterance, only the former should be of interest to the linguist qua linguist (The latter 
may be of great interest to the anthropologist interested in, say, folk mythology). The entire reasoning Bloomfield develops here is based on the following working premise: not being a qualified linguist, the native informant's views about her own language cannot possibly have any scientific value - they may at best encapsulate generations of lay opinion on such matters. But such lay opinion cannot be the basis for a truly scientific study of language. Or, as one might infer from Labov's remark (cited earlier) by straightforward contraposition, not being an expert, the native cannot possibly have any privileged access to the objective, factual truth and, hence, if at all he does hit upon the truth, it will be by sheer fluke, rather than by considered judgement.

Bloomfield's advice on not letting folk linguistics 'contaminate' the scientific study of language has hardly ever been interrogated, let alone challenged (Cf. Rajagopalan, 1996). However, problems begin to appear as soon as we recognise that our language about language ('meta-language', to use the right term) is itself - as indeed it cannot be otherwise - first and foremost a language and that it should not therefore come as a surprise that, in spite of the unique qualities one might associate with the attribute of 'aboutness' that is believed to distinguish it, the so-called meta-language retains much of the folk wisdom about language that has long sustained folklinguistics. Indeed, it is arguable, that a metalanguage with all the attributes one would ideally like to saddle it with is more of a piece of dream, a veritable 'mare's nest' than an attainable goal. Even if that we not the case, until we can actually say that we have such an allpowerful metalanguage at our disposal, we would not be in position to say for sure that we have eliminated from scientific discourse about everyday language all the vestigial traces of folk wisdom.

There is some further - albeit indirect - evidence for the fact that the linguist's supposedly myth-free scientific discourse may not be all that myth-free after all. Thus some recent as well as not-sorecent studies on metaphor and its role in the way ordinary humans think about language have shown that the scientific discourse about 
language (or, if you like, the language of linguistics - by definition, the linguists' meta-language) is as much under the spell of metaphor as is the ordinary man's 'lay' discourse concerning the same. Reddy (1979) for one has convincingly argued that practically everything that is said about language, whether by the linguist or by the manin-the-street, only makes sense to the extent that it is in conformity with what he designates the 'conduit metaphor'. It is thanks to the metaphorical image of language as some sort of conduit that we so readily accept the idea that meanings are the sort of 'material' entities that can be 'transported' from one person to another, can be 'packed' in words and sentences, 'stored' for future use, etc. Reddy's point is that, had we learned to think of language through some other metaphor, many of our every ideas - and indeed many of our highly prestigious theories about reading, writing and the all the rest would simply not have been developed the way they were. But, argues Reddy, once accepted as a plausible way of conceptualising language, the conduit metaphor, as it were, gets a total hold on us, making us 'instinctively' reject all other potential candidates as bizarre and unintelligible.

The one important point that emerges from the discussion above is that it is impossible to draw a clear line separating the object language of the native speaker - the one the linguist wants to submit to a scientific analysis - and the metalanguage of the linguist, the one presumably unaffected by her own language. This is so because, as Reddy shows in his paper, the conduit metaphor influences the way the man in the street thinks of language, but also the way many of the highly influential theories of language are formulated and gain ready acceptance precisely in virtue of 'building on' what folkwisdom says about such matters. A case in point, discussed at some length by Reddy, is the idea of communication assumed by information theory which simply reproduces the metaphor of conduit.

The same point is explored in a much subtler fashion by Derrida in his paper, by now already a classic, 'Signature Event 
Context': "Following a strange figure of discourse, one first must ask whether the word or signifier 'communication' communicates a determined content, an identifiable meaning, a describable value. But in order to articulate and to propose this question, I already have had to anticipate the meaning of the word communication: I have had to predetermine communication as a vehicle, transport, or site of passage of a meaning, and of a meaning that is one." (Derrida, 1991: 82).

The fact remains, however, that modern linguistics is wedded to the idea that language can and must be studied totally objectively, and that studying a language objectively consists in positing an imaginary distinction between object language and metalanguage and, furthermore, proceeding on the assumption that the distinction holds, despite all the available evidence against maintaining any such water-tight distinction when one is trying to explicate ordinary, everyday languages. ${ }^{4}$

\section{3. Metalanguage and its underlying metaphysics}

The question to ask at this stage is: why is Modern Linguistics so concerned about keeping its own metalanguage hermetically sealed off from any contact with ordinary, everyday languages, the ones it seeks to understand and explicate? The answer is that the science of linguistics is founded upon a concept of identity, whose distinctive features include totality, integrity, authenticity and purity. We shall examine each one of these features and its role in recent theorising about language.

The idea of totality is quite evident in the way modern linguistics conceptualises its basic object of study viz., language. Notice, first of all, that the 'language' that the linguist typically refers to is not a language with a preceding indefinite article. There is a world of difference between 'a language' and 'language' as the linguist is given to theorising about. The latter, unlike the former, is not a 'thing' in the real world. In the real world, what you have are 
individual languages - like English, Portuguese, Spanish, TupiGuaraní etc. A language in this sense is a 'fluid' phenomenon. Its boundaries are extremely fuzzy. It is very often difficult to state where one language ceases to be and another takes over. The truth of the matter is that individual languages are defined on geo-political grounds and not linguistic ones. For instance, Hindi and Urdu are officially considered two different languages, although the two languages share practically the same syntax (the differences being negligible) and mutual intelligibility between the two is very high. On the other hand, a Venetian and a Neapolitan or, for that matter, a speaker of Cantonese and a speaker of Mandarin, are supposed to be both speakers of one and the same language, viz., Italian and Chinese, respectively - although, it is well-known that mutual intelligibility in this case is close to nil. The reason why Hindi and Urdu are considered different languages is that there is a long-drawnout religious animosity that divides the people who speak what would otherwise be considered just one language - 'Hindustani', as Gandhi insisted on calling it, by way of circumventing the political implications of the problem at hand.

The case of "Hindi-Urdu" is but one glaring example of how the concept " $a$ language" (as opposed to the linguist's characteristic use of the word "language" in either its generic or its abstract sense - the former being associated with the so-called Structural Linguistics, and the latter with the latter-day Generative Linguistics) is adamantly resistant to definition using only linguistic criteria.

The totalising gesture is closely tied to a certain yearning for integrity. Theoretical linguistics has tended to view individual languages as entities fully self-sufficient unto themselves. No language is inferior to or deficient in any other sense in relation to any other. All languages are equally efficacious as instruments of communication. Many believe that this principle of linguistic egalitarianism is among those that make modern linguistics a truly scientific enterprise (Cf. Sampson, 1980: passim for some interesting observations in this direction). 
Authenticity is an important hall-mark of the concept of identity that modern linguistics works with. It is implicit, for instance, in the way modern linguistic theory has elected to approach the idea of the native speaker of a language. Just as the idea of $a$ language is totalised to the point of making it look altogether unlike the ones to be come across in the real world, so too the idea of a native speaker is idealised to such an extent that it ceases to bear any resemblance whatsoever to the ones in flesh and blood that walk the face of this earth. Coulmas, who edited a volume of papers (Coulmas, 1981) addressing the thorny issue, has remarked recently in a tone of sheer exasperation: "For the past 15 years or so I have been haunted by the native speaker who seems to be elusive, changing identities (including sex) at will as he/she/it jumps from one paper to another. (Cf. Afendras et al, 1995:317)."

A clear example of the quest for authenticity is the recent emphasis on the use of authentic material in the teaching of foreign languages; the assumption here is that authenticity has to do with texts produced by the 'native speaker' of the language in question, for she and she alone has the right to legislate on matters of authenticity. Also, by definition - and, mind you, this has been a working premise of modern linguistics ever since its inception (recall Bloomfield's remarks on this) - all that the native speaker produces is grist to the linguist's mill. It is the commitment to the thesis of authenticity that makes the linguist insist on material 'from the horse's mouth' as the only evidence that can make or mar a given hypothesis.

The idea of authenticity ultimately rests on the notion of purity. It is this notion of purity that has traditionally made linguists look askance at all those real-life situations that seem to 'deviate' from the monolingual norm. Theoretical linguistics has always tended to look upon monolingualism, and within it monodialectalism, as the norm and all forms of multilingualism, and the use of 'makeshift' languages as pidgins as deviations from that norm. To put the matter differently, Modern Linguistics seems to have taken seriously the Biblical story of the Tower of Babel and with it the idea that the phenomenon of 
multiplicity of languages (especially as it occurs in one and the same community) is a problem to be tackled rather than a fact of the matter to be examined in its own right - or, at the very least with the aid of methods and techniques developed from a study of the more 'orderly' monolingual communities.'

Indeed, so great is the fear of 'contamination' by contact with an alien tongue that even linguists frequently fall a prey to considering all forms of language contact as situations causing political concern - the concern being, in the final analysis, how to guarantee the 'purity' of the languages involved or, equivalently, how to ward off the possibility of defilement due to linguistic profligacy and communicative promiscuity (The racist connotations of this are by no means a figment of one's free-riding imagination Cf. Rajagopalan, 1996). As a matter of fact, here as on many other issues, the linguist is simply letting herself be influenced by the folk-wisdom on these matters, with its characteristic distrust of alien tongues and the fear of the loss of identity through contact with them.

As with contact on the horizontal plane, so with contact along the vertical axis. Thus Antilla (1972:349) expresses his fear of contamination by the object language which he takes to be the occupational risk of those of his colleagues who use themselves as their native informants (a practice unheard of in the hey-day of the so-called Structural Linguistics, but increasingly popular with the introduction of the Generative paradigm). Here is how Antilla gives vent to his fear: "Once you have linguistic training, you spoil your native intuitions as a normal speaker, and you cannot write a psychologically real grammar for a normal speaker. Linguists are not normal speakers when they write grammars." (Italics mine).

\section{4. The ideology of identity}

That the concept of identity is the mainstay of Modern Linguistics is indisputable (See Rajagopalan (1998a), for detailed discussion). What I want to argue from now on is that the very notion 
of identity is imbued with one or another ideology, a point which may not be immediately obvious. In order to see how identities are ideological constructs, the first step is to take note of the fact the very notion of identity of an individual (by etymology 'that which is undivided and indivisible') that we work with today is largely a 17th century invention. Prior to that, in the Middle Ages for instance, the identity of the individual was closely tied to social status and was an essentially unstable and volatile concept. It was only with the beginning of the modern period that the individual began to be viewed as an entity endowed with its own inalienable, essential, attributes. The genealogy of the modern concept of the individual has been meticulously worked out by Michael Oakeshott. ${ }^{6}$

In light of the discussion above, it should come as no surprise that linguistics is an ideological enterprise through and through to the extent that it simply takes for granted and uses as a corner-stone a certain concept of identity that is itself a product of a certain ideology. Nor should it surprise anyone that, depending on what sort of an individual you take the subject of language to be, you are necessarily - albeit, possibly, unconsciously - aligning yourself with one or another political ideology, in so far as political ideologies are invariably centred around some notion of the individual or another.

Thus it is that Bakhtin/Voloshinov (1973) can take the entire idealist tradition to task for concentrating on the individual psyche. By contrast, a Marxist linguist would rather construct her theory of language, using as subject an individual defined sociologically. Jacob Mey (1981:75) reacts to the idealist's subject with unconcealed impatience and disdain: “...there is nothing 'born' about the speakers' ability to speak. If anything, the physical event of birth is important only because it marks the beginning of a possible socialisation. Socialisation, however, is not an abstract event. It is a process that takes place in a concrete society.... For humans, it's natural to be social. Their nature is society." (italics mine)

What Mey and others like him who profess a Marxist orientation to language are insisting on is that human language is first 
and foremost a social phenomenon. This is bluntly denied by Chomsky when he identifies his own theoretical stance as naturalism, which he goes on define as follows: "By 'naturalism' I mean 'methodological naturalism,' counterposed to 'methodological dualism': the doctrine that in the quest for theoretical understanding, language and mind are to be studied in some manner other than the way we investigate natural objects, as a matter of principle ... this is a doctrine that few may espouse, but that dominates much practice." (Chomsky, 1995:28)

And among the few that, according to Chomsky, do espouse the view contrary to the one he advocates, is the American philosopher Hillary Putnam, a self-confessed Marxist, who is quoted as saying: "Many questions, including those of great human significance, one might argue, do not fall within naturalistic inquiry; we approach them in other ways." (Putnam 1993; cited in Chomsky 1995: 51). With his emphasis on innate, biologically inherited characteristics as the distinguishing trait of the subject of language, the kind of individual that emerges from the Chomskyan approach to language is just the opposite of Bakhtin/Voloshinov's. It has all the trimmings of liberalism, as ably analysed by Gray (1986:x), who identifies the following four points as the key elements of the liberalist outlook: (a) individualism (b) egalitarianism (c) universalism and (d) meliorism. Also, one can readily recognise in Chomsky's subject of language the liberal conception of the individual, whose primary attributes have been identified by Fraser and Lacey (1993: 45 - cited in Rampton, 1995: 234). According to Fraser and Lacey, from a liberal point of view, the individual is (a) a-historical (b) comes into the world with essential characteristics, which proceed from her very humanity and (c) is an essentially and orally 'disembodied self'what makes her a person - a moral subject - are pre-social or transcendent features of human beings. 


\section{THE DÉNOUMENT: CONCLUDING REMARKS}

The principal objective of this paper was, as announced in Section 1, to make a case for paying attention to the ideological implications of theories of language. In my view, the topic has yet to attain the importance it deserves. Part of the reason why I think it has not received adequate attention from linguists in general is that there is a wide-spread belief among us that theory or science is ideologically neutral. Linguistic theory, many believe, is only concerned with the facts of the matter. Facts belong to the nature of things. And Nature knows no ethics. What is woefully missing in this sort of reasoning is the realisation that theories do not drop like manna from heaven: they are, all of them, without exception, manmade products. As man-made products, they cannot but reproduce the ideological orientations of those who put them forward. This means that, far from being opposed to each other as the conventional wisdom on the matter would have us believe, theory and ideology may, in the final analysis, turn out to be simply two sides of the very same coin.

Unfortunately, however, when linguists $d o$ raise questions of political and ideological overtones, they generally do it as part of an attempt to re-write the history of their discipline. Frederick Newmeyer's celebrated attempts at linguistic historiography are case in point.(Cf. Newmeyer, 1980, 1986). People like Newmeyer proceed on the assumption that it is possible to write the true history of an academic discipline - a history, that is to say, totally unaffected by the personal whims and predilections of the one who writes it. Schlieben-Lange (1989), in fact, explicitly expounds such a view. In my view, the quest for a true history of linguistics or, for that matter, anything under the sun, is bound to end up as a wild goose chase (See Rajagopalan, 1989) for a detailed discussion of this view). This is so because, in order to be able to write such an unbiased history, the historiographer will need to have access to a vantage point outside of the field of study she wishes to examine and contemplate things in a spirit of total non-involvement. It so happens, however, 
that there simply is no such vantage point. You can only write the history of an academic discipline by consciously assuming a position within the bounds of that very discipline and assuming such a position is inescapably an ideological gesture. Restivo (1988) has observed in relation to the world of mathematics - the academic discipline that many regard as the bastion of pure reason where human factors have no place whatsoever: "Even when I carry out scientific work ....., an activity I can seldom conduct in direct association with other men - I perform a social, because human act. It is not only the material of my activity - like the language itself which the thinker uses - which is given to me as a social product. My own existence is a social activity."

And, as for the prospects of writing a neutral, thoroughly dispassionate, history, Dell Hymes (1980: 648) is straight to the point when he says "It is particularly hard for any one of us to draw a line between setting history straight and settling old scores." But Newmeyer for one is absolutely committed to the legitimacy of pursuing what he calls 'autonomous linguistics' which he contrasts with the 'humanistic approach' and the 'sociological orientation'. According to him, the advocates of the autonomous linguistics "... approach language as a natural scientist would study physical phenomena, that is, by focusing on those aspects of its properties that exist apart from either the beliefs and values of the individual speakers of language or the nature of the society in which the language is spoken." (Newmeyer, 1986: 5-6). It is arguable, however, that in so doing what the autonomous linguist might in fact be accomplishing is winnowing those aspects of language that do seem to lend themselves to an analysis of the sort routinely conducted in the so-called 'natural sciences' from those other aspects that resist it, and quite arbitrarily claiming that only the aspects of the former type count as the real essence of language. (Cf. Botha, 1987; Love, 1988).

Contrary to Newmeyer's position, I would argue that the split between the autonomy theorists on the one hand and the humanists 
and the sociologically inclined linguists on the other is a pseudo opposition. If at all there is a line to be drawn, it has to be between those who are not in the least bothered about the ideological implications of their own theorising and those who are (Fairclough, 1989 a \& b; Pennycook, 1995). This makes Newmeyer's own role as a scholar somewhat problematic, since he also claims to be a Marxist by ideological persuasion.

Nor does the line between those who are conscious of the ideological implications of their own work and those who are not (and also who, like Widdowson 1994 expressly reject it) coincide with the (in my view) thoroughly baseless distinction between theoretical linguistics and what by sheer exclusion becomes applied linguistics (Cf. Rajagopalan, 1993). As Rampton (1995) remarks, until very recently it was fashionable among those who carried the banner of the break-way discipline to claim their own work as "neutral terminologies" (See, for instance, Corder, 1973-12-13; Munby, 1978; Phillipson, 1992:65ff).

But then, from the stand-point of the autonomy theorists, all those who do not toe their party line are wasting their time looking at what is merely of marginal interest. And this would include all those whose research interests happen to be in some 'hyphenated' sub-discipline or another. Toolan (1989: 274) refers to the autonomy theorists as 'competence linguists' and observes that “... [the] competence linguist's very manoeuvre of demarcation, in which an allegedly value-free core is sealed off from parasitic hyphenated subdisciplines, is a thoroughly ideological effort of marginalisation with immense moral consequences" (italics mine).

The situation we are considering here is a matter of the sociology of knowledge rather than the philosophy of science (cf. Rajagopalan, 1998b). For, at the institutional level, it is power politics pure and simple. Some 20 years ago, William O'Barr (1976) made the following observation: "There are no important theories about how language is different from other political issues (if indeed it is), about how what might be called politico-linguistics differs from 
sociolinguistics, or about how language factors intervene in and thus affect the outcome of political issues."

Clearly, the idea of a hyphenated sub-discipline to be called politico-linguistics is a very modest proposal (as indeed it is bound to be viewed as, given, as we have just noted, the tendency to downplay the importance of all hyphenated areas) in comparison with the much stronger claim made in this paper, viz., that theory itself is invariably impregnated by ideology. But even the weaker claim advanced by O'Barr is yet to receive serious attention from the community of linguists. The road ahead is, therefore, very long indeed and no doubt, unexpected twists and turns!

\section{NOTES}

${ }^{1}$ The research reported in this paper is part of an ongoing project (No. 306151/ 88-0), financed by the Conselho Nacional de Desenvolvimento Cientifico e Tecnológico (CNPq).

${ }^{2}$ It has been pointed out, though, that "... though different in style and flavor, there are no differences in empirical content or range between the prescriptively phrased statement 'Never end a sentence with a preposition' and the nonprescriptively phrased statement 'No sentence ends with a preposition'" (Sanders, 1974: 4). (See Rajagopalan, 1984 for further comments). What is at stake here is, however, the difference between prescriptivism and descriptivism in so far as they are different attitudes of the researcher vis-à-vis the world; in the ultimate analysis, it all boils down to a question of whether or not theory impinges on the real world.

${ }^{3}$ It is interesting to note that in some countries like Britain the universities seem to differ from one another when it comes to classifying linguistics. At Lancaster University which has an important Centre for Language in Social Life, linguistics is explicitly classified in the prospectus as a "social science". By contrast, the University of Edinburgh which used to boast what was probably the country's most important Department of Applied Linguistics today offers an M.Sc. (Master of Science) in linguistics, instead of the M.A. (Master of Arts) degree the students received until not very long ago after successfully completing a post-graduate course. 
${ }^{4}$ It is ironic indeed that Alfred Tarski, the Polish-American logician, whose pineering work in the field of metamathematics significantly contributed to the formal study of metalanguages, was nevertheless sceptical of the usefulness of the notion of metalanguage when it came to the study of natural (as opposed to formal) languages (Cf. Tarski, 1944).

${ }^{5}$ Says Romaine (1989: 3): "It would be certainly odd to encounter a book with the title Monolingualism. However, it is precisely a monolingual perspective which modern linguistic theory takes as its starting point in dealing with basic analytic problems such as the construction of grammars and the nature of competence."

${ }^{6}$ To quote him, "The first demand for those intent upon exploring the intimations of individuality was for an instrument of government capable of transforming the interests of individuality into rights and duties. To perform this task government required three attributes. First, it must be single and supreme; only by a concentration of all authority at one centre could the emergent individual escape from the communal pressures of family and guild, of church and local community, which hindered his enjoyment of his own character. Secondly, it must be an instrument of government not bound by prescription and therefore with authority to abolish old rights and create new; it must be a 'sovereign' government. And this, according to current ideas, means a government in which all who enjoyed rights were partners, a government in which the 'estates' of the realm were direct or indirect participants. Thirdly, it must be powerful - able to preserve the order without which the aspirations of individuality could not be realized; but not so powerful so as to constitute a new threat to individuality." (368-9)

\section{REFERENCES}

AFENDRAS, E. A. et al. On "new/non-native" Englishes: a gamelan. Journal of Pragmatics, 24.3, 295-321, 1995.

ANTILLA, C. An introduction to Historical and Comparative Linguistics. New York: Macmillan, 1972.

BAKHTIN, M. M. VOOSINOV, V. N. Marxism and the Philosophy of Language. New York: Seminar Press, 1973.

BLOOMFIELD, L. Why a linguistic society. Language 1.1. 1-5, 1925. Reprinted in HOCKETT, C. F. A Leonard Bloomfield anthology. Bloomington: Indiana University Press, 109-112, 1970.

. Secondary and tertiary responses to language. Language, 20, 45-55, 1944. 
BOTHA, R. P. The generative garden game: challenging Chomsky at conceptual combat. University of Stellanbosch, 1987.

CÂMARA JR., J. M. Estrutura da Língua Portuguesa. 2. ed. Petrópolis: Vozes, 1970.

CAMERON, D. Feminism and linguistic theory. London: Macmillan, 1985.

CATTELL, N. P. The new English Grammar: a descriptive introduction. Cambridge, Mass.: The MIT Press, 1966.

Language and nature. Mind, 1-61, 1995.

CORDER, S. P. Introducing Applied Linguistics. Harmondsworth: Penguin, 1973.

DERRIDA, J. Signature event context. In: Margins of Philosophy. Chicago University Press. Reprinted in KAMUF, P. (Ed.). A Derrida reader: between the blinds. New York: Harvester Wheatsheaf, 80-111, 1972/1991.

FAIRCLOUGH, N. Language and power. London: Longman, 1989a.

. Discourse and social change. Cambridge: Polity Press, 1989b.

FRASER, E., LACEY, N. The politics of community: a feminist critique of the liberalcommunitarian debate. Hempel Hamstead: Harvester Wheatsheaf, 1993.

GRAY, J. Liberalism. Milton Keynes: Open U.P., 1986.

HYMES, D. Review of Stormy Petrel in Linguistics, by R. Hall Jr., Ithaca, New York: Language Services, 1975. Language, 56. 3, 648-652, 1980.

LABOV, W. Resolving the neo-grammarian controversy. Language, 57. 2, 267308, 1981.

. Objectivity and commitment in linguistic science: the case of Black English trial in Ann Arbor. Language in Society, 11, 165-201, 1982.

LOVE, N. Ideal linguistics. Language and Communication, 8. 1, 69-84, 1988.

MCCONNEL-GINET, S. Language and gender. In: NEWMEYER, F. J. (Ed.). Language: The socio-cultural context. Linguistics: The Cambridge survey IV. Cambridge: Cambridge U.P., 75-99, 1988.

MARX, K., ENGELS, F. The German ideology. 1845-7. In: MARX, K., ENGELS, F. Selected writings. London: Lawrence \& Wishart, 1958.

MUNBY, J. Communicative syllabus design. Cambridge: Cambridge U.P., 1978.

NEWMEYER, F. J. Linguistic theory in America. New York: Academic Press, 1980. The politics of Linguistics. Chicago: Chicago U.P., 1986.

OAKESHOTT, M. The masses in representative democracy. In: Rationalism in Politics and other essays. Indianapolis: Liberty Press, 363-383, 1991.

O'BARR, W. M. The study of language and politics. In: O'BARR, W. M., O'BARR J.F. (Eds.). Language and Politics. The Hague: Mouton, 1976. 
PUTNAM, H. Replies. In: TOMERLIN, J. E. (Ed.). Philosophical topics, 20, 347408, 1993.

PHILLIPSON, R. Linguistic imperialism. Oxford: Oxford University Press, 1992.

RAJAGOPALAN, K. Grammar: the bee in the linguist's bonnet vs. the thorn in the language teacher's flesh. Anais do V ENPULI. São Paulo: PUC-SP, 182192, 1984.

. Sobre a indissociabilidade do historiar a lingüística do próprio fazer da lingüística. D.E.L.T.A., 5. 2, 225-240, 1989.

. On the history of myth and myth of history. Proceedings of XXIII Seminar of the SENAPULLI. São Paulo, 121-124, 1991.

. Chameleon linguist and the revival of casuistry: afterthoughts on a controversial suggestion by Fernando Tarallo. D.E.L.T.A., 9, Especial, 339352, 1993.

. On listening for nietzschean echoes in J. L. Austin's philosophical discourse. Letras \& Letras, 10.1 \& 2. 89-106, 1994.

. Critical Discourse Analysis and its discontents. Working Papers Series, 72. Lancaster: Lancaster University, 1995.

. On the ideological underpinnings of the theory of speech acts. Revista de Estudos da Linguagem. 5. 4, 105-132, 1996.

. Linguistics and the myth of nativity: comments on the controversy over "new/non-native Englishe". Journal of Pragmatics, 27, 225-231, 1997 a.

. Formalismo vs. funcionalismo: sobre as premissas ocultas dessa polêmica. Anais do $1^{\circ}$ Encontro do CEL-SUL. 1. 1, 25-33, $1997 \mathrm{~b}$.

. A ideologia do suprimido: ou como não teorizar a respeito de ideologia. D.E.L.T.A., 14. 1, 121-139, 1998 a.

. O conceito de identidade na lingüística: é chegada a hora para uma reconsideração radical? In: SIGNORINI (Ed.). Lingua(gem) e identidade. Campinas: Mercado de Letras, 21-40, 1998b.

. On the theoretical trappings of the thesis of anti-theory; or, why the idea of theory may not, after all, be all that bad: a response to Gary Thomas. Harvard Educational Review. 67. 3, 335-352, 1998c.

. (Forthcoming). Between Marx and Derrida: an exercise in literary semantics. To appear in the Journal of Literary Semantics.

RAMPTON, B. Politics and change in research in Applied Linguistics. Applied Linguistics, 16. 2, 233-256, 1995.

REDDY, M. The conduit metaphor - a case of frame conflict in our language about language. In: ORTONY, A. (Ed.). Metaphor and thought. Cambridge: Cambridge U.P., 284-324, 1979. 
RESTIVO, S. The social life of mathematics. Philosophica. 42, 5-20, 1988.

ROMAINE, S. Bilingualism. Oxford: Basil Blackwell, 1989.

SAMPSON, G. Schools of Linguistics: competition and evolution. London: Hutchinson, 1980.

SANDERS, G. A. Issues of explanation in linguistics. In: COHEN, D. (Ed.). Explaining linguistic phenomena. N.Y.: John Wiley \& Sons, 1-20, 1974.

SCHLIEBEN-LANGE, B. Reflexões a respeito do escrever sobre a história da lingüística. D.E.L.T.A., 5. 1, 1-22, 1989.

SIMPSON, P. Language, ideology and point of view. London: Routledge, 1993.

TARSKI, A. The semantic conception of truth. Philosophy and Phenomenological Research. 4, 342-375, 1944.

TOOLAN, M. Review of R. Harris: The Language Machine. Language in Society. 18. 2, 269-275, 1989.

WIDDOWSON, H. Explorations in Applied Linguistics. Oxford: Oxford U.P., 1972. . Discourse analysis: a critical view. (Draft version). Paper presented at Lanaster Applied Linguistic Seminar. Unpublished manuscript, 1994. . Review of N. Fairclough: Discourse and Social Change. Applied Linguistics. 16. 4, 510-516, 1995.

WILKINS, D. A. Linguistics in language teaching. London: Edward Arnold, 1972. 